\title{
Identification of immunogenic proteins and generation of antibodies against Salmonella Typhimurium using phage display
}

\author{
Torsten Meyer ${ }^{1}$, Thomas Schirrmann ${ }^{1}$, André Frenzel ${ }^{1}$, Sebastian Miethe ${ }^{1}$, Janin Stratmann-Selke ${ }^{2,3}$, \\ Gerald F Gerlach², Katrin Strutzberg-Minder ${ }^{2}$, Stefan Dübel ${ }^{1}$ and Michael Hust ${ }^{*}$
}

\begin{abstract}
Background: Solely in Europoe, Salmonella Typhimurium causes more than 100,000 infections per year. Improved detection of livestock colonised with S. Typhimurium is necessary to prevent foodborne diseases. Currently, commercially available ELISA assays are based on a mixture of O-antigens (LPS) or total cell lysate of Salmonella and are hampered by cross-reaction. The identification of novel immunogenic proteins would be useful to develop ELISA based diagnostic assays with a higher specificity.

Results: A phage display library of the entire Salmonella Typhimurium genome was constructed and 47 immunogenic oligopeptides were identified using a pool of convalescent sera from pigs infected with Salmonella Typhimurium. The corresponding complete genes of seven of the identified oligopeptids were cloned. Five of them were produced in E. coli. The immunogenic character of these antigens was validated with sera from pigs infeced with S. Tyhimurium and control sera from non-infected animals. Finally, human antibody fragments (scFv) against these five antigens were selected using antibody phage display and characterised.

Conclusion: In this work, we identified novel immunogenic proteins of Salmonella Typhimurium and generated antibody fragments against these antigens completely based on phage display. Five immunogenic proteins were validated using a panel of positive and negative sera for prospective applications in diagnostics of Salmonela Typhimurium.
\end{abstract}

\section{Background}

Salmonella spec. is a genus of the Enterobacteriaceae. Two species are in the genus Salmonella: S. bongeri and $S$. enterica [1]. Salmonella enterica is classified in serogroups and serovars on the basis of their $\mathrm{O}$ - and $\mathrm{H}$-antigens (somatic and flagellar antigens) [2,3]. So far, 2800 Salmonella enterica gene families and more than 2500 serovars are known. More than 1500 serovars belong to the subspecies Salmonella enterica subspecies enterica [4]. These pathogens cause foodborne gastrointestinal infections, usually through raw poultry and pork, but it can also be found in non-alcoholic beer or seafood. The subspecies enterica is the cause of $99 \%$ of human Salmonella

\footnotetext{
* Correspondence: m.hust@tu-bs.de

'Technische Universität Braunschweig, Institut für Biochemie, Biotechnologie und Bioinformatik, Abteilung Biotechnologie, Spielmannstr.7, 38106

Braunschweig, Germany

Full list of author information is available at the end of the article
}

infections. The prevailent serovars are Typhimurium and Enteritidis [4-7]. The most reported phage types for Salmonella Typhimurium are DT193, U302 and DT104. Infections with the latter two phage types increased in 2009 [5]. Human infections with phage type DT104 are particularly critical, because these strains are resistant to most of the commonly used antibiotics [6]. In Europe, Salmonella caused more than 130,000 reported infections in 2008 and 108,614 cases in 2009. In the US more than a million cases are estimated to occur $[5,8]$.

Improved detection o f livestock colonised with $S$. Typhimurium would be very helpful to prevent foodborne diseases. In particular, infections in swine are difficult to diagnose, because the animals develop either no or only slight symptoms [9]. Only through continuous monitoring of the herds infections of humans can be prevented. Established methods for $S$. Typhimurium diagnostics are classically time-consuming, using microbiological cultures on 
different liquid and solid media [10,11], specific fluorescence labeled DNA probes [12], PCR [13] or recently, a quantum dot-based bead assay [14]. Currently, high throughput diagnostic of $S$. Typhimurium is performed by indirect ELISA $[9,15,16]$. The commercially available ELISA kits e. g. SALMOTYPE ${ }^{\circledR}$ - or Enterisol ${ }^{\circledR}$-ELISA use a mixture of O-antigens of Salmonella enterica subspecies entirca serovars. They are based on the system established by Nielson et al. [15]. Because of this mixture, crossreactions occur with other bacteria [15]. In addition, the sensitivity varies between the different ELISA assays [17]. For a sensitive and specific ELISA, immunogenic and species specific proteins are required [18]. The improvement of detection methods, as well as the development of new vaccines would be facilitated by the identification, characterisation and validation of previously unknown immunogenic proteins.

The most common method for the identification of immunogenic proteins is 2D-PAGE of cultured bacterial pathogens and immunoblot using sera from infected patients or animals followed by mass spectrometry or microsequencing [19-24]. However, this method is limited. Differentially expressed proteins, e.g. dependent on pathogen-host interaction, can not be detected. Furthermore, weakly expressed antigens may also not be identified. In these cases, antigen phage display may circumvent these limitations. Our approach for the identification of immunogenic proteins is phage display. Phage display technology was invented by George P. Smith [25]. This methods can be used both for the selection of antibodies [26-29] and for the identification of immunogenic proteins from genomic or cDNA libraries [30-34]. Here, the cloning of randomly fragmented genomic DNA or cDNA into phage display vectors should allow, in theory, the display of all polypeptides encoded by the genome of the donor or all polypeptides encoded by the transcriptome of the donor, respectively $[35,36]$. In this study, we combined the identification of immunogenic proteins by M13 phage display using genomic libraries from $S$. Typhimurium with the selection of open reading frames without any subcloning steps (Figure 1 left part) in order to improve the library quality $[37,38]$.

Afterwards, the genes corresponding to the identified immunogenic oligopeptides were cloned and produced in $E$. coli (Figure 1 middle part). Using our phage display based pipeline for the generation of human antibodies [39], we were able to generate human, recombinant antibodies against these antigens (Figure 1 right part).

\section{Results}

Generation of the Salmonella Typhimurium genomic phage display library

Sonication of Salmonella DNA did not lead to clonable DNA fragments, whereas the sonication of E. coli DNA as a control could be cloned without problems (data not shown). Therefore, genomic DNA was digested with a mixture of the 4 base pair cutters $D p n \mathrm{I}$ and $A l u \mathrm{I}$ and the 6 base pair cutter AfeI to construct the Salmonella Typhimurium genome library (Figure 2A). The digested DNA was cloned into pHORF3 [38] resulting in a library with $1.6 \times 10^{6}$ independent clones. The insert rate and size was analysed by colony PCR (Figure 2B), which indicated that more than $90 \%$ of the clones contain an insert. The shortest inserts had a size of about $40 \mathrm{bp}$ while the longest inserts had a lenght of 2500-3000 bp with an average length of about 500-800 bp. For the selection of open reading frames, the library was packaged with Hyperphage [37,40,41]. The packaged library was also analysed by colony PCR (Figure 2C) resulting in shorter DNA fragments compared to the initial library.

\section{Selection of immunogenic Salmonella Typhimurium oligopeptides}

Pooled convalescent serum from pigs infected with Salmonella Typhimurium was used for the panning procedure. In total, two panning rounds were performed and 184 oligopeptide phage clones were analysed by ELISA for binding to serum IgGs. 58 oligopeptide phage clones with different gene fragments were found to bind to the porcine convalescent serum IgGs but not to the control serum IgGs. For 19 gene fragments, no homologous NCBI database hit was found. 31 of the identified proteins showed a higher similarity to other Salmonella entericia serovars (Table 1). One of the selected gene fragments showed the best NCBI database hit to Salmonella Typhimurium, but the gene fragment was not in frame (Table 2). Seven oligopeptide phage clones with a good signal to noise ratio (three- to four-fold over background) in the ELISA and the highest homology to genes from Salmonella enterica spp. enterica serovar Typhimurium were selected for further characterisation (Table 3). Binding of the oligopeptide phage to convalescent serum IgGs, including the non-Salmonella Typhimurium hits and the out of frame Salmonella Typhimurium hit, was verified in an additional ELISA with piglet serum as negative control (data not shown).

\section{Cloning of the complete ORFs of the identified oligopeptides and antigen production}

The correspoding complete protein coding sequence of the identifed gene fragments was amplified from genomic DNA (Figure 3A) and cloned into pET21A+. When the ORF contained a leader peptide, it was replaced by the pelB leader peptide by cloning into $\mathrm{pET} 21 \mathrm{~A}+$ pelB. It was not possible to amplify the putative carbohydrate kinase encoding gene from the genomic DNA. The antigens were produced in $500 \mathrm{~mL}$ scale shake flasks, purified by IMAC and verified by SDS-PAGE (Figure 3B). Five of six antigens 


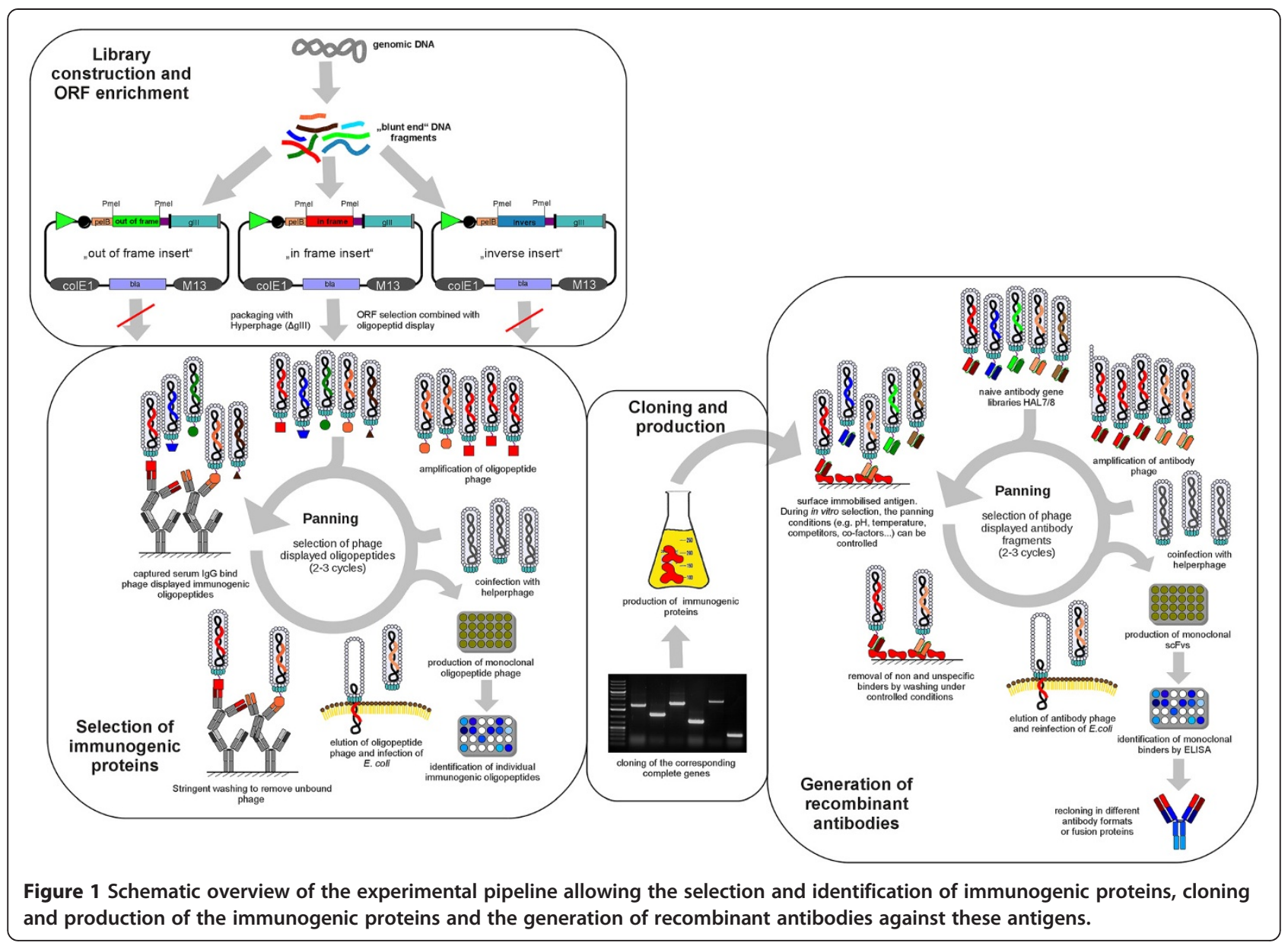

cloned into pET21A + were produced and purified successfully. It was not possible to produce the hypothetical protein STM14.

\section{Analysis of the identified immunogenic proteins with different pig sera}

The five full size antigens were tested with sera from ten Salmonella Typhimurium positive classified pigs, using the commercial SALMOTYPE Pig Screen ELISA, and sera from four negative classified pigs. In addition, they were tested with the pooled immune positive sera used for the selection procedure and with a piglet serum as negative control (Figure 4).

9 out of 10 positive sera bound better to the antigen putative dihydroxyacid dehydratase compared to the negative sera. This means, that 9 of the 10 positive sera had a higher ELISA O.D. value compared to the negative serum with the highest ELISA O.D. value.

7 out of 10 positive sera bound better to the antigen putative electron transfer protein alpha compared to the negative sera. The pooled immune sera (positive control) contained either more or better binders against the antigens than any of the individual positive classified samples.

7 out of 10 positive sera bound better to the antigen 2,4dieonyl-CoA-reductase compared to the negative sera. Here, the piglet serum revealed a high antigen binding capacity compared to the mixture of positive sera.

8 out of 10 as positive classifed sera bound better to the antigen phage tail-like protein compared to the negative classified sera.

8 out of 10 as positive classified sera bound better to the antigen putative dimethyl sulphoxide reductase compared to the negative classified sera.

Not all individual positive sera bound significantly better than all four individual negative sera. However, in general the positive sera showed better binding to all identified immunogenic proteins compared to the negative sera.

Generation of recombinant human antibodies against the identified immunogenic proteins

Antibody fragments against all five antigens were selected using the human naive antibody gene library 


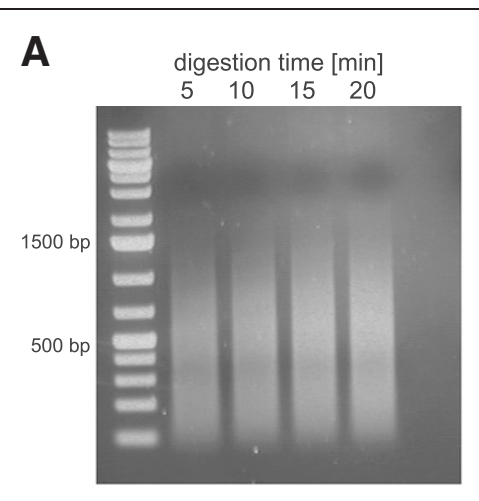

B
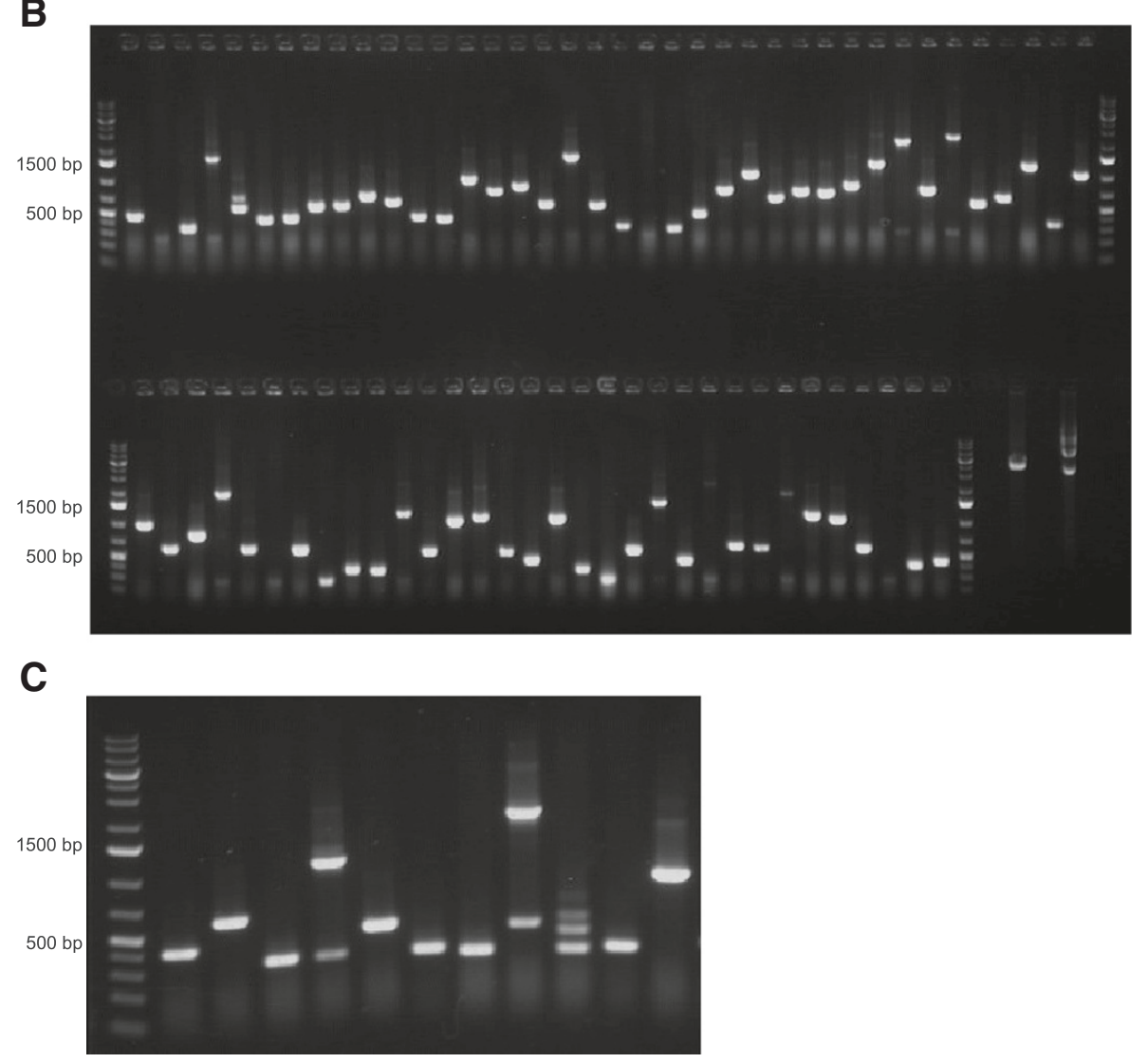

Figure 2 A agarose gel of the digested genomic DNA of Salmonella Typhimurium. B agarose gel of a colony PCR of the cloned genomic fragments. $\mathbf{C}$ agarose gel of a colony PCR of the inserts of Hyperphage packed phagemids.

HAL7/8 [39]. Monoclonal binders were identified by antigen ELISA using soluble scFv fragments (data not shown). These binders were sequenced to identify unique binders and analysed using VBASE2 (www. vbase2.org) [42]. Human antibodies were successfully generated against all five antigens.

The best binders were recloned into the pOPE101-XP vector [43], produced in $1.6 \mathrm{~L}$ scale in the LEX system and IMAC purified (Table 4). The yields were between $0.5 \mathrm{mg} / \mathrm{L}$ and $12 \mathrm{mg} / \mathrm{L}$. Afterwards, the purified $\mathrm{scFv}$ were analysed by titration ELISA (Figure 5). The EC50 values of the $\mathrm{scFv}$ (monovalent) are given in Table 4. For four $\mathrm{ScFv}$ it was not possible to determine the EC50, since the maximal binding was not reached in the titrations ELISA.

\section{Analysis scFv binding to Salmonella proteins by immunoblot}

Binding to linear epitopes was analysed by SDS-PAGE of the antigens, followed by a Western Blot and an immunostain using the purified scFv. All binders to putative dihydroxyacid dehydratase, phage tail-like protein and 
Table 1 Selected immunogenic Salmonella enterica proteins (without Salmonella serovar Typhimurium), including in frame and out of frame with glll gene fragments

\begin{tabular}{|c|c|c|c|c|}
\hline Protein & $\begin{array}{l}\text { In frame } \\
\text { with gllI }\end{array}$ & $\begin{array}{l}\text { pHORF } 3 \\
\text { insert size } \\
\text { [bp] }\end{array}$ & $\begin{array}{l}\mathrm{NCBI} \\
\text { reference } \\
\text { sequence }\end{array}$ & $\begin{array}{l}\text { Assigned } \\
\text { Salmonella } \\
\text { serovar }\end{array}$ \\
\hline ATP-dependent Clp protease ATP-binding subunit & yes & 232 & ZP_04657262 & Tennessee \\
\hline outer membrane ferrichrome receptor protein precursor & yes & 58 & YP_002635837 & Paratyphi C \\
\hline Rhs-family protein & yes & 100 & ZP_04657793 & Tennessee \\
\hline hypothetical protein SentesTyphi_03066 & yes & 294 & ZP_03357516 & Typhi \\
\hline crotonobetaine/carnitine-CoA ligase & no & 135 & YP_002635709 & Paratyphi C \\
\hline transposase B & no & 144 & ZP_03224077 & Kentucky \\
\hline DNA polymerase I & no & 348 & ZP_03381877. & Typhi \\
\hline nitrate reductase 2 , gamma subunit & no & 89 & ZP_03366843 & Typhi \\
\hline putative phage terminase, large subunit & no & 648 & YP_002216031 & Dublin \\
\hline putative electron transfer flavoprotein alpha subunit & yes & 58 & YP_002636467 & Paratyphi C \\
\hline hypothetical protein & no & 414 & ZP_06535866 & Typhi \\
\hline \multicolumn{5}{|l|}{ Salmonellaentericaenterica_12643 } \\
\hline exonuclease $V$ subunit gamma & no & 86 & ZP_04653610 & Tennessee \\
\hline bacteriophage Mu tail sheath protein & no & 182 & ZP_02663881 & Schwarzen-grund \\
\hline pts system, glucose-specific iibc component & no & 109 & ZP_02670079 & Heidelberg \\
\hline flagellar basal body P-ring protein & no & 60 & ZP_03371027 & Typhi \\
\hline hth-type tranScriptional regulator & no & 710 & ZP_02698922 & Newport \\
\hline DNA mismatch repair protein & yes & 122 & YP_002638485 & Paratyphi C \\
\hline colanic acid biosynthesis protein WcaK & no & 270 & ZP_02830210 & Weltevreden \\
\hline outer membrane fimbrial usher protein & yes & 171 & ZP_03336471 & Typhi \\
\hline uroporphyrinogen-III synthase & yes & 49 & ZP_03385917 & Gallinarium \\
\hline ATP-dependent metalloprotease & yes & 130 & ZP_03385917 & Typhi \\
\hline aminoglycoside/multidrug efflux system & yes & 67 & ZP_04657455. & Tennessee \\
\hline penicillin-binding protein & no & 56 & ACN47454 & Paratyphi C \\
\hline C32 tRNA thiolase & yes & 123 & ZP_03365647 & Typhi \\
\hline hypothetical protein SG0660 & no & 324 & YP_002225743. & Gallinarium \\
\hline putative LysR-family transcriptional regulator & no & 48 & AET55395 & Gallinarium \\
\hline $23 \mathrm{~S}$ rRNA methyluridine methyltransferase & yes & 214 & ZP_03356931 & Typhi \\
\hline hypothetical protein SeHA_C2934 & yes & 55 & YP_002046718 & Heidelberg \\
\hline putative transport protein & yes & 55 & ACN44236. & Paratyphi C \\
\hline hypothetical protein SPC_0823 & yes & 61 & ZP_03365355 & Typhi \\
\hline nitrate reductase, alpha subunit & yes & 298 & ZP_03217505 & Virchow \\
\hline
\end{tabular}

putative dimethyl sulphoxide reductase bound linear epitopes. Three of the four binders to putative electron transfer protein alpha and the binder against 2,4-

Table 2 Selected immunogenic Salmonella Typhimurium proteins with out of frame gene with glll fragments in pHORF3

\begin{tabular}{|c|c|c|c|}
\hline Protein & & $\begin{array}{l}\text { pHORF3 } \\
\text { insert } \\
\text { size [bp] }\end{array}$ & $\begin{array}{l}\text { NCBI } \\
\text { reference } \\
\text { sequence }\end{array}$ \\
\hline $\begin{array}{l}\text { maltose } \\
\text { protein }\end{array}$ & ABC transporter & periplasmic260 & NP_463094 \\
\hline
\end{tabular}

dienoyl-CoA-reductase did not bind in the immunoblot (Table 4).

\section{Discussion}

Antibody phage display for generation of recombinant antibody fragments [39,44-47] and the identification of immunogenic proteins by phage display $[30-32,38,48,49]$ are established methods. But in this work, for the first time a complete phage display based pipeline from antigen identification to the generation of the corresponding antibody fragments was shown. Oligopeptide phage 
Table 3 Selected immunogenic Salmonella Typhimurium proteins

\begin{tabular}{|c|c|c|c|}
\hline Protein & $\begin{array}{l}\text { pHORF3 } \\
\text { insert } \\
\text { size [bp] }\end{array}$ & $\begin{array}{l}\text { NCBI } \\
\text { reference } \\
\text { sequence }\end{array}$ & $\begin{array}{l}\text { Molecular } \\
\text { mass } \\
\text { complete } \\
\text { protein }[k D a]\end{array}$ \\
\hline $\begin{array}{l}\text { putative } \\
\text { dihydroxyacid } \\
\text { dehydratase }\end{array}$ & 118 & NP_462432 & 62 \\
\hline $\begin{array}{l}\text { putative electron transfer } \\
\text { protein alpha }\end{array}$ & 58 & NP_459833 & 33 \\
\hline $\begin{array}{l}\text { 2,4-dienoyl-CoA- } \\
\text { reductase }\end{array}$ & 52 & NP_462133 & 73 \\
\hline phage tail-like protein & 70 & NP_461635 & 23 \\
\hline $\begin{array}{l}\text { putative dimethyl } \\
\text { sulphoxide reductase }\end{array}$ & 148 & NP_460459 & 90 \\
\hline $\begin{array}{l}\text { hypothetical protein } \\
\text { STM14 }\end{array}$ & 58 & ACY86745 & 7 \\
\hline $\begin{array}{l}\text { putative carbohydrate } \\
\text { kinase }\end{array}$ & 40 & CBG27384 & 72 \\
\hline
\end{tabular}

display technology can expand the identification of immunogenic proteins compared to 2D-PAGE followed by mass spectrometry or microsequencing $[32,38,48,50]$. The identification of immunogenic proteins via oligopeptide phage display is independent of the natural expression rate of the immunogenic protein, which also allows the identification of low abundant proteins or proteins only produced in host-pathogen interactions. A disadvantage could be that only oligopeptides can be selected which can be secreted by the SEC pathway [38]. Interestingly, when using sonicated $S$. Typhimurium DNA, the transformation rates were in the range of $10^{2}-10^{4}$ clones per transformation. This is very low compared to the transformation rates of $10^{5}$ for sonicated genomic DNA of Mycoplasma hyopneumoniae or $10^{6}$ clones for E. coli [38]. Hence, the sonication method appeared to be not applicable for some bacteria species or strains when constructing genomic libraries.
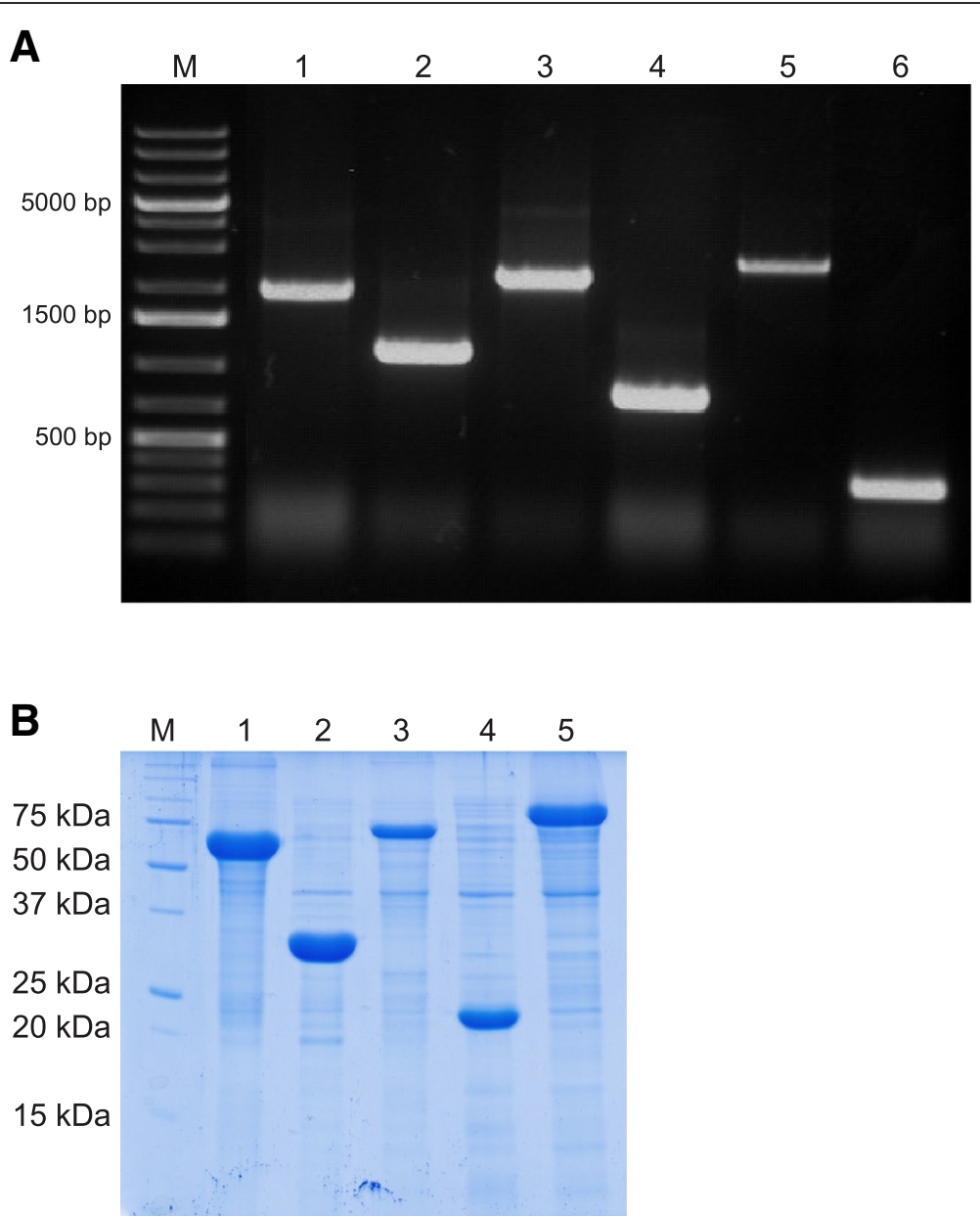

Figure 3 A agarose gel of seven PCR amplified identified genes. M: marker; 1: putative. dihydroyacid dehydratase; 2: putative electron transfer protein alpha; 3: 2,4-dienyl-CoA reductase, 4: phage tail like protein; 5: putative dimethyl sulphoxide reductase; 6: hypothecial protein STM14. B SDS-PAGE (12\%) of five $\mu \mathrm{L}$ elution fraction of six IMAC purified immunogenic proteins. M: marker; 1: putative dihydroyacid dehydratase; 2: putative electron transfer protein alpha; 3: 2,4-dienyl-CoA reductase, 4: phage tail like protein; 5: putative dimethyl sulphoxide reductase. 


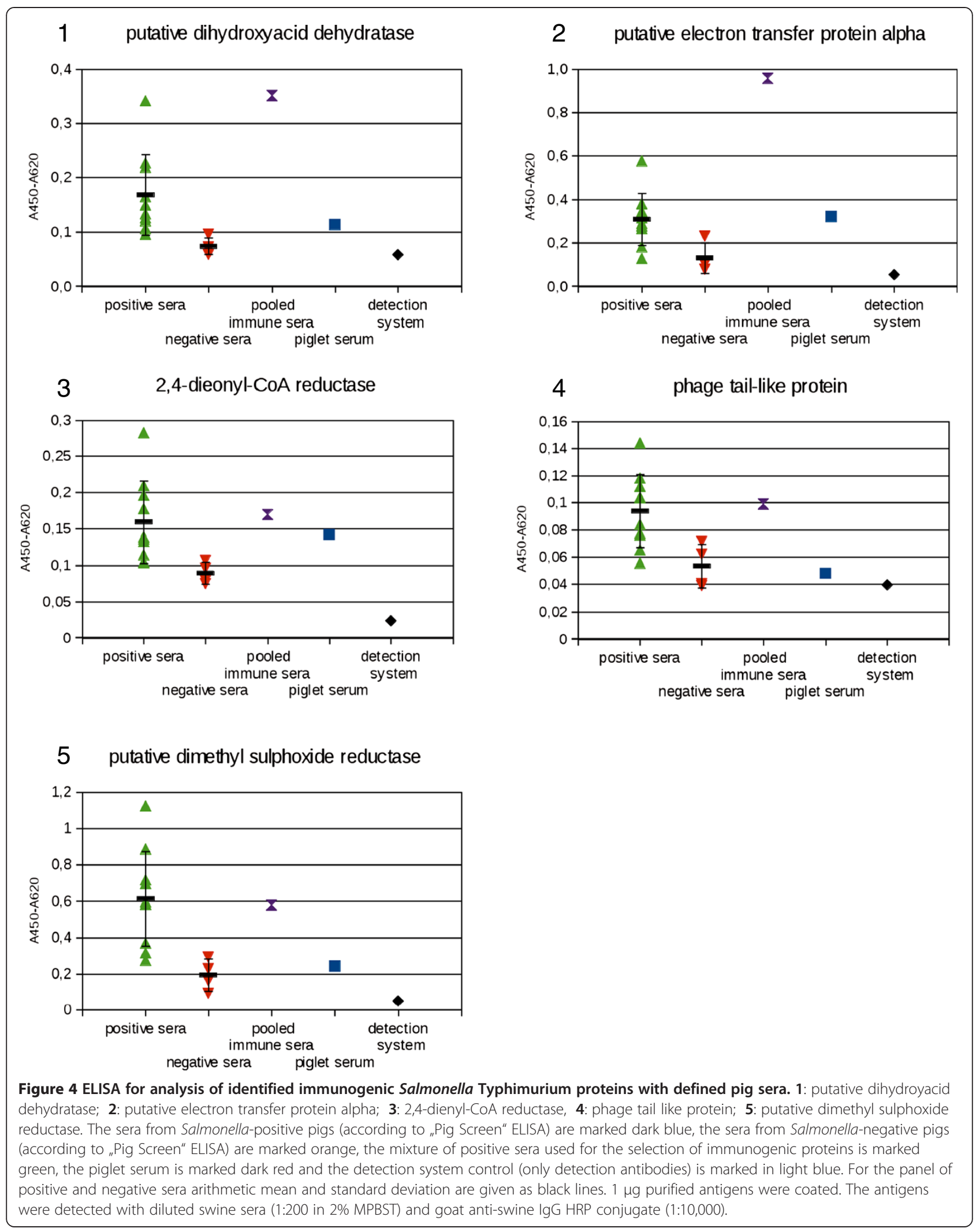




\begin{tabular}{|c|c|c|c|c|c|c|c|}
\hline scFv & Target & $\mathrm{VH}$ & $V L$ & Yield $[\mathrm{mg} / \mathrm{L}]$ & $E C 50[\mathrm{nM}]$ & $E C 50[\mu \mathrm{g} / \mathrm{mL}]$ & Immuno-blot \\
\hline TM228.2.3-B1 & putative dihydroxyacid dehydratase & IGHV3-48*03 & IGLV3-19*01 & 3.8 & 40 & 1.2 & yes \\
\hline TM228.2.3-D9 & putative dihydroxyacid dehydratase & IGHV3-23*01 & IGLV1-50*01 & 8.4 & 160 & 4.6 & yes \\
\hline TM228.2.3-H7 & putative dihydroxyacid dehydratase & IGHV1-18*01 & IGLV3-19*01 & 12.0 & 310 & 9.4 & yes \\
\hline TM228.3.3-A5 & putative electron transfer protein alpha & IGHV1-46*01 & IGLV7 & 4.3 & 78 & 2.3 & yes \\
\hline TM228.3.3-C5 & putative electron transfer protein alpha & - & IGLV3-21*02 & 7.9 & n.d. & n.d. & no \\
\hline TM228.3.3-D3 & putative electron transfer protein alpha & IGHV5-51*01 & IGLV3-1*01 & 7.6 & n.d. & n.d. & no \\
\hline TM228.3.3-F10 & putative electron transfer protein alpha & $\mid G H V 1-46^{*} 01$ & IGLV3-19*01 & 0.5 & n.d. & n.d. & no \\
\hline TM228.4.3-A4 & 2,4-dienoyl-CoA-reductase & IGHV3-15*01 & IGLV3-19*01 & 1.3 & 310 & 9.4 & no \\
\hline TM228.5.3-G7 & phage tail-like protein & IGHV1-2*02 & IGLV1-47*01 & 7.4 & 310 & 9.4 & yes \\
\hline TM228.6.3-A12 & putative dimethyl sulphoxide reductase & IGHV1-69*01 & IGLV3-19*01 & 1.1 & n.d. & n.d. & yes \\
\hline TM228.6.3-C5 & putative dimethyl sulphoxide reductase & IGHV4-31*03 & IGLV1-44*01 & 1.5 & 625 & 18.8 & yes \\
\hline TM228.6.3-H2 & putative dimethyl sulphoxide reductase & IGHV4-59*01 & IGLV1-44*01 & 2.8 & 625 & 18.8 & yes \\
\hline
\end{tabular}

The $\mathrm{V}$ genes are given according to VBASE2 (www.vbase2.org).

In this work, 58 different oligopeptides were bound by convalescent serum from pigs infected with Salmonella Typhimurium. Interestingly, many of the encoding gene fragments were not in frame with gIII and therefore, in theory, should not result in the production of functional oligopeptide-pIII fusion proteins. However, similar observations, that gene fragments encoding oligo- or polypeptides frequently contain frameshifts, have been described previously for selections by phage display $[37,51]$. For +1 frameshifts it is reported that oligo- or polypeptides are still displayed on phage particles with the same amino acid sequence as the corresponding constructs without a frameshift. One suggested explanation of this effect was the occurrence of RNA secondary structures. A second explanation could be the selection pressure against oligo- or polypeptides which are toxic for E. coli and thus may lead to a negative selection against these potential toxic proteins [52].

The most frequently identified oligopeptides did not show the best match with the Salmonella serovar Typhimurium (NCBI taxonomy IDs: 99287, 588858 and 568708), but instead with other Salmonella serovars. These antigens with a higher homology to other Salmonella serovars, could be interesting for further analyses. However in this work, we focused on the seven antigens with the highest homology to Salmonella Tyhphimurium. In contrast to former selections of immunogenic proteins using the pHORF system, where both new and known immunogenic proteins were selected [32,38], these seven antigens have not been described as immunogenic before. So far, five immunogenic proteins of $S$. Typhimurium were found using 2D-PAGE [53]. Putative dihydroxyacid dehydratase, putative dimethyl sulphoxide reductase and hypothetical protein STM14 of
Salmonella Typhimurium have not been described as immunogenic before. The putative electron transfer protein alpha [54] is located on a pathogenicity island [55]. To date, 2,4-dienoyl-CoA-reductase of $S$. Typhimurium has not been identified as immunogenic, but interestingly, humans exhibiting anti-mitochondrial autoantibodies (AMA-positive), have also antibodies against the human 2,4-dienoyl-CoA-reductase [56]. For the phage tail-like protein, a bactericidal activity is described for some bacteria, e.g. Pseudomonas [57]. Immunogenic proteins from $S$. Typhimurium, which are used for diagnostics, are only rarely described in the literature. Described are OmpD [58] and a preparation of flagelates [59] for ELISA diagnostics. For nanobead based assays polyclonal antibodies against Salmonella were used whereupon the detailed antigens are unknown [14]. The $\mathrm{V}$ genes of the selected scFv against the five immunogenic proteins are mainly derived from the HV families 1 and 3 and from the LV families 1 and 3. Member of these gene families are preferentially selected from naive scFv libraries [60,61]. Only scFv with a lambda VL but no kappa VL were selected. Interestingly, also one VL domain only binder was selected. This is an artefact from library cloning since the insert rate of HAL7 is not $100 \%$ [39]. Functional VL domain dAbs have been described before [62].

The gold standard for diagnostics of Salmonella infections is microbiological culture [18]. Currently, for high throughput detection of $S$. Typhimurium, ELISA is the ideal method $[9,15,16,58]$. The commercially available ELISA kits use a mixture of O-antigens (LPS) or total cell lysate of Salmonella enterica subspecies entirca serovars. This mixture of antigens causes, cross-reactions with other bacteria [9,18]. A 


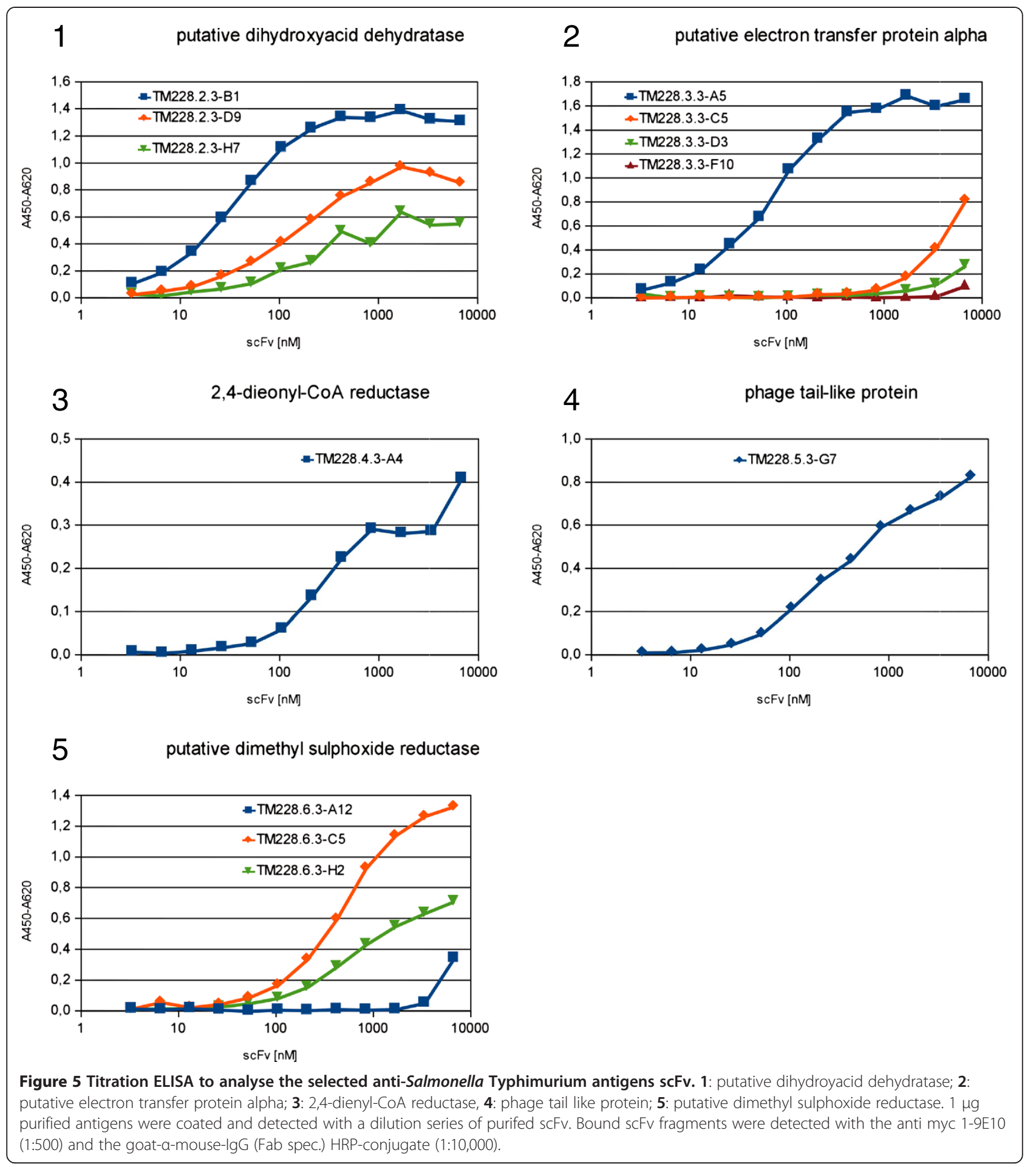

comparison of four different ELISA detection systems showed "both sample matrices, blood sera and meat juice, are suitable for antibody detection. However, the test sensitivity mainly depends on the respective cutoff used for the specific test" and "our findings indicate that the currently used LPS-ELISA systems have diagnostic uncertainties..." [9]. The use of one or a defined mixture of the selected immunogenic proteins and the corresponding antibody fragments will be useful to establish an ELISA based diagnostic kit with a higher specificity compared to the commercially available diagnostic kits. 


\section{Methods}

Construction of the Salmonella Typhimurium genomic phage display library

Salmonella Typhimurium was cultivated in 2xTY medium [63] overnight at $34^{\circ} \mathrm{C}$ and $250 \mathrm{rpm}$. For isolation of genomic DNA, $6 \mathrm{x} 3 \mathrm{ml}$ of the culture were used. The isolation was performed with the Quiaamp DNA Mini Kit according to the manufacturer's instructions (Qiagen, Hilden, Germany). After purification, the DNA was digested for $35 \mathrm{~min}$ using three different blunt endcutting restriction endonucleases $(A l u \mathrm{I}, A f e \mathrm{I}, D p n \mathrm{I})$ (NEB, Frankfurt, Germany). DNA fragments with a size up to $1200 \mathrm{bp}$, were used for cloning into the PmeIrestricted vector pHORF3 [38]. The ligated plasmids were transformed into E. coli Top10 F' (Invitrogen, Karlsruhe, Germany) by electroporation.

\section{Enrichment of ORFs using Hyperphage}

The enrichment of ORFs in the S. Typhimurium genomic library requires the display of the corresponding polypeptides on phage particles for the panning. Therefore, the library was packaged using Hyperphage $[40,41]$ as described previously $[37,38]$.

\section{Colony PCR}

E. coli clones bearing pHORF3 were analysed by colony PCR using the primers MHLacZPro_f (5' GGCTCGTATG TTGTGTGG 3'), MHgIII_r (5' GGAAAGACGACAAAA CTTTAG $3^{\prime}$ ), and the following protocol: $94^{\circ} \mathrm{C} 1 \mathrm{~min}, 56^{\circ} \mathrm{C}$ $0.5 \mathrm{~min}, 72^{\circ} \mathrm{C} 1.5 \mathrm{~min}, 25$ cycles. The DNA was separated by $1 \%$ Agarose gel electrophoresis.

\section{Selection of immunogenic oligopeptides (Panning)}

The panning was performed by following the protocol described before [38] with modifications. Six wells of a MaxiSorp ${ }^{\circledR}$ 96-well microtitre plate (MTP; Nunc, Wiesbaden, Germany) were coated with $150 \mu \mathrm{L} 5 \mu \mathrm{g} / \mathrm{mL}$ goat anti-swine IgG in PBS [63] overnight. The wells were washed with phosphate buffered saline (PBS) supplemented with $0.1 \%$ Tween20 (PBST) (Roth, Karlsruhe, Germany). Afterwards, they were blocked with PBST supplemented with $2 \%(\mathrm{w} / \mathrm{v})$ skim milk powder $(2 \%$ MPBST) for $1 \mathrm{~h}$. In parallel, several wells of a MaxiSorp ${ }^{\circledR}$ plate were coated with $150 \mu \mathrm{L} 1 \times 10^{11} \mathrm{cfu} / \mathrm{mL}$ Hyperphage in PBS overnight and blocked with $2 \%$ MPBST for $1 \mathrm{~h}$. All washing steps were performed three times using PBST buffer and an enzyme-linked immunosorbent assay (ELISA) washer (Tecan Columbus, Crailsheim, Germany). A swine serum mixture (obtained from pigs after infection with $S$. Typhimurium and field sera) was diluted 1:10 in 2\% MPBST and pre-incubated on MaxiSorp ${ }^{\circledR}$ MTP wells coated with Hyperphage for $1 \mathrm{~h}$ at RT, to remove serum IgG binding to the helperphage. After pre-incubation, the swine serum was incubated in goat anti-swine IgG-coated MTP wells for $2 \mathrm{~h}$. After washing, $5 \times 10^{10} \mathrm{cfu}$ polypeptide phage particles of the Hyperphage-packaged Salmonella Typhimurium genomic library were incubated on the captured swine IgGs for $2 \mathrm{~h}$. For the following panning rounds, $100 \mu \mathrm{L}$ of amplified phage of the previous panning round were used. The non-binding polypeptide phage particles were removed by ten stringent washing steps. In the second and third panning round, the number of washing steps was increased to 20 and 30, respectively. Elution of bound phage particles was performed using $200 \mu \mathrm{L}$ of $10 \mu \mathrm{g} / \mathrm{ml}$ trypsin $(10 \mu \mathrm{g} / \mathrm{mL}$ trypsin in PBS) for $30 \mathrm{~min}$ at $37^{\circ} \mathrm{C}$. Ten microlitres of the eluted phage solution were used for titration. Twenty millilitres of the E. coli TOP10 $\mathrm{F}^{\prime}$ cells were grown to an $\mathrm{OD}_{600}$ of $0.4-0.5$ which were then infected with the remaining $190 \mu \mathrm{L}$ of the eluted phage solution and incubated for $30 \mathrm{~min}$ at $37^{\circ} \mathrm{C}$. Afterwards, the cells were harvested by centrifugation for $10 \mathrm{~min}$ at $3.220 \times \mathrm{g}$. The bacterial pellet was resuspended in $250 \mu \mathrm{L} 2 \times \mathrm{TY}$ medium $(1.6 \%$ [w/v] tryptone, $1 \%[\mathrm{w} / \mathrm{v}]$ yeast, $0.5 \%[\mathrm{w} / \mathrm{v}] \mathrm{NaCl})$ containing $100 \mathrm{mM}$ glucose and $100 \mu \mathrm{g} / \mathrm{mL}$ ampicillin $(2 \times$ TY-GA), plated onto $15 \mathrm{~cm}$ $2 \times$ TY-GA agar plates and incubated overnight at $37^{\circ} \mathrm{C}$. Grown colonies were harvested in $5 \mathrm{~mL} 2 \times$ TY-GA medium using a Drigalsky spatula. Fifty millilitres of $2 \times$ TY-GA medium were inoculated with $200 \mu \mathrm{L}$ bacteria culture and grown to an $\mathrm{OD}_{600}$ of $0.4-0.5$ at $37^{\circ} \mathrm{C}$ and $250 \mathrm{rpm}$ in a shaking incubator. Five millilitres of bacterial culture corresponding to about $\sim 2.5 \times 10^{9}$ cells were infected with $5 \times 10^{10} \mathrm{cfu}$ Hyperphage, incubated at $37^{\circ} \mathrm{C}$ for $30 \mathrm{~min}$ without shaking and another $30 \mathrm{~min}$ with shaking at $250 \mathrm{rpm}$. The infected cells were harvested by centrifugation for $10 \mathrm{~min}$ at $3.220 \mathrm{xg}$. The pellet was resuspended in $30 \mathrm{~mL}$ 2xTY medium containing $100 \mu \mathrm{g} /$ $\mathrm{mL}$ ampicillin and $50 \mu \mathrm{g} / \mathrm{mL}$ kanamycin $(2 \times \mathrm{TY}-\mathrm{AK})$. Phage particles were produced at $30^{\circ} \mathrm{C}$ and $250 \mathrm{rpm}$ overnight. On the following day, the supernatant containing phage particles was collected.

\section{Production of individual oligopeptide phage clones for screening}

For phage production, polypropylene 96-well U bottom plates (Greiner bio-one, Frickenhausen, Germany) containing $175 \mu \mathrm{L} 2$ xTY-GA per well were inoculated with single $E$. coli colonies from the phage titration plates of the third panning round and incubated at $37^{\circ} \mathrm{C}$ with constant shaking at $850 \mathrm{rpm}$ (thermo shaker PST60HL4, lab4you, Berlin, Germany) overnight. A new plate with $165 \mu \mathrm{L} 2$ xTY-GA per well was inoculated with 10 $\mu \mathrm{L}$ of the overnight cultures and incubated at $37^{\circ} \mathrm{C}$ and $850 \mathrm{rpm}$ for $2 \mathrm{~h}$. Afterwards, the bacteria were infected with $5 \times 10^{9} \mathrm{cfu}$ Hyperphage/well and incubated at $37^{\circ} \mathrm{C}$ without shaking for $30 \mathrm{~min}$, followed by shaking at $850 \mathrm{rpm}$ for $30 \mathrm{~min}$. The MTP plate was centrifuged at 
3,220xg for $10 \mathrm{~min}$ and the supernatants were discarded. Afterwards, the bacterial pellets were resuspended in $175 \mu \mathrm{L} /$ well 2xTY containing $100 \mathrm{mg} / \mathrm{mL}$ ampicillin and $30 \mu \mathrm{g} / \mathrm{mL}$ kanamycin (2xTY-AK) and incubated at $30^{\circ} \mathrm{C}$ at $850 \mathrm{rpm}$ overnight for phage production. The bacteria were pelleted again and the supernatants were transferred to a new plate. The phage were precipitated with $1 / 5$ volume $20 \% \mathrm{PEG} / 2.5 \mathrm{M} \mathrm{NaCl}$ solution at $4^{\circ} \mathrm{C}$ for $1 \mathrm{~h}$ and centrifuged at 3,220xg for $1 \mathrm{~h}$. The phage pellet was dissolved in $150 \mu \mathrm{L}$ PBS and residual bacteria were removed by another centrifugation at 3,220xg for $5 \mathrm{~min}$. The phage containing supernatants were stored at $4^{\circ} \mathrm{C}$ or directly used for ELISA.

\section{Screening of individual oligopeptide phage clones}

For phage ELISA, the produced polypeptide phage particles were captured. Here, $100 \mu \mathrm{L}$ of $250 \mathrm{ng} / \mathrm{mL}$ mouse anti-M13 (B62-FE2, Progen, Freiburg, Germany) in PBS were coated at $4^{\circ} \mathrm{C}$ overnight. After coating the wells were blocked with $2 \%$ MPBST. Between each incubation step the wells were washed three-times with PBST using an ELISA washer. $150 \mu \mathrm{L}$ of the monoclonal phage production were incubated for $2 \mathrm{~h}$. The pig convalescent serum was diluted 1:200 in 2\% MPBST supplemented with $1 / 10$ volume $E$. coli cell lysate and $1 \times 10^{10} \mathrm{cfu}$ Hyperphage/mL, added to the captured phage particles and incubated for $2 \mathrm{~h}$. The bound pig IgGs were detected with goat anti-swine IgG conjugated with horseradish peroxidase (HRP) (1:1000) for $1.5 \mathrm{~h}$ and visualised with TMB (3,3',5,5'-tetramethylbenzidine) substrate. The staining reaction was stopped by adding $100 \mu \mathrm{L} 1 \mathrm{~N}$ sulphuric acid. The absorbances at $450 \mathrm{~nm}$ and scattered light at $620 \mathrm{~nm}$ were measured and the $620 \mathrm{~nm}$ value was subtracted using a SUNRISE microtiter plate reader (Tecan, Crailsheim, Germany).

\section{Cloning of the fullsize gene fragments}

The corresponding proteins of the identified immunogenic polypeptides were amplified by PCR using the genomic DNA and the following oligonucleotide primers: TM208-forward (5' AAGGAGATATACATATGAGC CAAAAATGTCAACATGCT 3'), TM208-reverse (5' CTCGAGTGCGGCCGCTTTAAGCCAGGCTCCGGCC ATTAA 3`) for putative dihydroxyaciddehydratase, TM209-forward (5' AAGGAGATATACATATGGCTTC TTTAGTTATTGCTGAACAT 3'), TM209-reverse (5' CTCGAGTGCGGCCGCTAATTTATCGATAAGTTCA GGTAC 3') for putative electron transfer protein alpha, TM210-forward (5' AAGGAGATATACATATGAGCTA CCCGTCGCTGTTCGCCCCG 3’), TM210-reverse (5' CTCGAGTGCGGCCGCAATCTCCAGTGCCAGTCGG GTGCC 3') for 2,4-dieonyl-CoAreductase, TM211forward (5' AAGGAGATATACATATGAATAGTCTGT TGCCGCCGGGTTCG3'), TM211-reverse (5' CTCGA
GTGCGGCCGCTGGATTCACTCTCATTGTGTCAAT 3') for phage tail-like protein, TM212-forward (5' CAG CCGGCCATGGCTTCAATGAATAAAGCAGTCAGTA GTGAG 3'), TM212-reverse (5' CTCGAGTGCGGCCG CACGTGCCGGGCGGTATTCGCGCCA 3') for putative carbohydratekinase, TM213-forward (5' CAGCCGG CCATGGCTGCGGTGCAGCAGGCTATGCGCAACG AA 3'), TM213-reverse (5' TGCGGCCGCAAGCTT GATTTTTTCGATTTCCACCAGATTTGT 3') for putative dimethyl sulphoxide reductase chain $\mathrm{A} 1$, and TM214-forward (5' AAGGAGATATACATATGATGTC AGCATGTTTTTTTGGCCGA 3'), TM214-reverse (5' CTCGAGTGCGGCCGCATCAATTATTTTGGTGAGT GTTTG 3') for hypothetical protein STM14. The PCR was performed using the following protocol: $98^{\circ} \mathrm{C} 30 \mathrm{sec}$, $98^{\circ} \mathrm{C} 10 \mathrm{sec}, 60^{\circ} \mathrm{C} 20 \mathrm{sec}, 72^{\circ} \mathrm{C} 120 \mathrm{sec}, 24$ cycles. The DNA was separated by electrophoresis in a $1 \%$ agarose gel. The bands of interest were cut out from the gel, the DNA was eluted and used for cloning into pET21A + or pET21A + pelB. After ligation the plasmids were transformed into $E$. coli BLR-DE3. Positive clones were identified by using colony PCR using the oligonucleotide primers MHpET21_f1 (5' GAGCGGATAAC AATTCCCC 3') and MHpET21_r1 (5' GCAGCCAACT CAGCTTCC 3').

\section{Production of the immunogenic proteins}

Five hundred $\mathrm{mL}$ 2xTY-GA medium were inoculated with $5 \mathrm{~mL}$ overnight culture and cultivated to an O.D. 600 of 1.0 at $37^{\circ} \mathrm{C}$ and $250 \mathrm{rpm}$. The expression was induced with $1 \mathrm{mM}$ IPTG (final concentration) overnight. Cells were harvested by centrifugation at $7.500 \mathrm{xg}$ for $15 \mathrm{~min}$. Lysis was performed with $1 \mathrm{mg} / \mathrm{mL}$ lysozyme and $5 \mu \mathrm{g} /$ $\mathrm{mL}$ DNAseI in $15 \mathrm{~mL}$ His-tag binding buffer $\mathrm{pH} 7.4$ (20 mM Na $2 \mathrm{HPO}_{4}, 0.5 \mathrm{M} \mathrm{NaCl}, 10 \mathrm{mM}$ Imidazol). For Isolation of inclusion bodies $8 \mathrm{M}$ Urea was added. The purification was performed under denaturing conditions with FastFlow Sepharose (GE Healthcare) loaded with nickel. The Sepharose was washed with $10 \mathrm{mM}, 30 \mathrm{mM}$ and $60 \mathrm{mM}$ imidazole $\left(20 \mathrm{mM} \mathrm{Na} \mathrm{HPO}_{4}, 0.5 \mathrm{M} \mathrm{NaCl}\right.$, 10,30 or $60 \mathrm{mM}$ Imidazol). For elution, $5 \mathrm{~mL} 100 \mathrm{mM}$ EDTA in PBS supplemented with $8 \mathrm{M}$ urea were used.

\section{SDS-PAGE}

Antigens were analysed by $12 \%$ SDS-PAGE using a Protean II Minigel system (BioRad Inc, München, Germany) according to [63]. Protein gels were stained with coomassie blue.

\section{Enzyme linked immunosorbent assay (ELISA) for verification of immunogenic proteins}

One $\mu \mathrm{g}$ of antigen was coated to 96 well microtitre plates (MaxiSorp, Nunc) in $50 \mathrm{mM} \mathrm{NaHCO} 3 \mathrm{pH} 9.6$ overnight at $4^{\circ} \mathrm{C}$. After coating, the wells were washed three times with PBST and blocked with 2\% MPBST for 
$1.5 \mathrm{~h}$ at RT, followed by three washing steps with PBST. For serum ELISA, sera were diluted 1:200 in $100 \mu \mathrm{L}$ $2 \%$ MPBST and incubated in the antigen coated plates for $1.5 \mathrm{~h}$ at RT, followed by three PBST washing cycles. Bound pig IgGs were detected with goat anti-swine IgG HRP conjugate $(1: 10,000)$ (Dianova, Hamburg, Germany). The visualisation was performed with TMB $\left(3,3^{\prime}, 5,5^{\prime}\right.$-tetramethylbenzidine) as a substrate and the staining reaction was stopped by adding $100 \mu \mathrm{l} 1 \mathrm{~N}$ sulphuric acid. Absorbance at $450 \mathrm{~nm}$ was measured by using a SUNRISE ${ }^{\mathrm{rm}}$ microtitre plate reader (Tecan, Crailsheim, Germany).

\section{Generation of antibodies against the identified antigens}

The selection of recombinant antibodies was performed according to [64] with modificiations. In short, pannings were performed in 96 well microtitre plates (MaxiSorp, Nunc, Wiesbaden, Germany). One $\mu$ g of antigen was coated in PBS pH 7.4 [63] overnight at $4^{\circ} \mathrm{C}$. The antigen-coated wells and wells for the preincubation of the library were blocked with $2 \%$ MPBST. In each case $2.5 \times 10^{11}$ phage particles of the human naive antibody gene libraries HAL7 and HAL8 [39] were diluted in PBST with $1 \%$ skim milk and $1 \%$ bovine serum albumin (BSA) and preincubated for $1 \mathrm{~h}$. The supernatant, containing the depleted library, was incubated in the antigen-coated wells at RT for $2 \mathrm{~h}$ followed by 10 washing steps with PBST. Afterwards, bound scFv phage particles were eluted with $200 \mu \mathrm{L}$ trypsin solution $(10 \mu \mathrm{g} /$ $\mathrm{mL}$ trypsin in PBS) at $37^{\circ} \mathrm{C}$ for $30 \mathrm{~min}$. The supernatant containing eluted $\mathrm{scFv}$ phage particles was transferred into a new tube. Ten $\mu \mathrm{L}$ of eluted scFv phage were used for titration as described before [64]. Twenty $\mathrm{mL} E$. coli XL1-Blue MRF' (Agilent, Böblingen, Germany) culture in the logarithmic growth phase (O.D. ${ }_{600}=0.4-0.5$ ) were infected with the remaining $\mathrm{scFv}$-phage at $37^{\circ} \mathrm{C}$ for $30 \mathrm{~min}$ without shaking. The infected cells were harvested by centrifugation for $10 \mathrm{~min}$ at $3220 \mathrm{xg}$ and the pellet was resuspended in $250 \mu \mathrm{L} 2 \mathrm{xTY}$ medium [63] supplemented with $100 \mathrm{mM}$ glucose and $100 \mu \mathrm{g} / \mathrm{mL}$ ampicillin (2xTY-GA), plated on a $15 \mathrm{~cm} 2 \mathrm{xTY}$ agar plate supplemented with $100 \mathrm{mM}$ glucose and $100 \mu \mathrm{g} /$ $\mathrm{mL}$ ampicillin and incubated overnight at $37^{\circ} \mathrm{C}$. Grown colonies were harvested with $5 \mathrm{~mL} 2 \mathrm{xTY}-\mathrm{GA}$. Thirty $\mathrm{mL}$ of 2xTY-GA were inoculated with $100 \mu \mathrm{L}$ of the harvested colony suspension and grown to an O.D.600 of 0.4 to 0.5 at $37^{\circ} \mathrm{C}$ and $250 \mathrm{rpm}$. Five $\mathrm{mL}$ bacteria suspension $\left(\sim 2,5 \times 10^{9}\right.$ bacteria) were infected with $5 \times 10^{10}$ helperphage M13K07 (Stratagene), incubated at $37^{\circ} \mathrm{C}$ for $30 \mathrm{~min}$ without shaking, followed by $30 \mathrm{~min}$ at $250 \mathrm{rpm}$. Infected cells were harvested by centrifugation for $10 \mathrm{~min}$ at $3220 \mathrm{xg}$ and the pellet was resuspended in $30 \mathrm{~mL}$ 2xTY supplemented with $100 \mu \mathrm{g} / \mathrm{mL}$ ampicillin and $50 \mu \mathrm{g} / \mathrm{mL}$ kanamycin (2xTY-AK). Antibody phage were produced at $30^{\circ} \mathrm{C}$ and $250 \mathrm{rpm}$ for $16 \mathrm{~h}$. Cells were harvested by centrifugation for $10 \mathrm{~min}$ at $3220 \mathrm{xg}$. The supernatant containing the antibody phage $\left(\sim 1 \times 10^{12} \mathrm{cfu} /\right.$ $\mathrm{mL}$ ) were directly used for the next panning round or stored at $4^{\circ} \mathrm{C}$ for a few days.

\section{Production of scFv in microtitre plates (MTPs)}

The identification of monoclonal binders was performed as described before [43]. In brief, 96-well MTPs with polypropylene (PP) wells (U96 PP $0.5 \mathrm{~mL}$, Greiner, Frickenhausen, Germany) containing $150 \mu \mathrm{L}$ phosphate buffered 2xTY-GA [63] (2xTY-GA supplemented with $10 \%(\mathrm{v} / \mathrm{v})$ potassium phosphate buffer $\left(0.17 \mathrm{M} \mathrm{KH}_{2} \mathrm{PO}_{4}\right.$, $\left.0.72 \mathrm{M} \mathrm{K}_{2} \mathrm{HPO}_{4}\right)$ ) were inoculated with colonies from the titration plate of the third panning round. MTPs were incubated overnight at $37^{\circ} \mathrm{C}$ at $1000 \mathrm{rpm}$ in a MTP shaker (Thermoshaker PST-60HL-4, Lab4You, Berlin, Germany). A volume of $180 \mu \mathrm{L}$ phosphate-buffered 2xTY-GA in PP-MTP well was inoculated with $10 \mu \mathrm{L}$ of the overnight culture and grown at $37^{\circ} \mathrm{C}$ and $800 \mathrm{rpm}$ for $2 \mathrm{~h}$. Bacteria were harvested by centrifugation for $10 \mathrm{~min}$ at $3220 \mathrm{xg}$ and $180 \mu \mathrm{L}$ supernatant were removed. The pellets were resuspended in $180 \mu \mathrm{L}$ buffered 2xTY supplemented with $100 \mu \mathrm{g} / \mathrm{mL}$ ampicillin, $100 \mathrm{mM}$ sucrose an $50 \mu \mathrm{M}$ isopropyl-beta $\mathrm{D}$ thiogalacto pyranoside (IPTG) and incubated at $30^{\circ} \mathrm{C}$ and $800 \mathrm{rpm}$ overnight. Bacteria were pelleted by centrifugation for $10 \mathrm{~min}$ at $3,220 \mathrm{xg}$ and $4^{\circ} \mathrm{C}$. The scFv-containing supernatant was transferred to a new PP-MTP and stored at $4^{\circ} \mathrm{C}$ before analysis.

\section{Identification of monoclonal scFv using ELISA}

Antigen coating was performed as described above (Enzyme linked immunosorbent assay (ELISA) for verification of immunogenic proteins). For identification of binders, supernatants containing monoclonal scFv were incubated in the antigen coated plates for $1.5 \mathrm{~h}$ at RT followed by three PBST washing cycles. Bound $\mathrm{scFv}$ were detected using murine mAb 9E10 which recognises the C-terminal c-myc tag and a goat anti-mouse serum conjugated with horseradish peroxidase (HRP) (Sigma; $1: 10,000)$.

The detection was performed as described above.

\section{Production of scFv in the LEX system}

The large-scale expression system (LEX) (Harbinger Biotech, Toronto, Canada) was used for production of scFv. E. coli (XL1-Blue-MRF') was cultivated in $2 \mathrm{~L}$ glass bottles up to a cultivation volume of $1.5 \mathrm{~L}$. To obtain sufficient oxygenation and mixing of the culture, the bottles were connected to an air manifold, which allows a general air flow rate of 4-6 L/min. A thermostat-controlled water bath was used for regulating the temperature of the cultivation. $50 \mathrm{ml}$ TB supplemented with $100 \mu \mathrm{g} / \mathrm{mL}$ 
ampicillin were inoculated with a glycerol stock of each $\mathrm{scFv}$ clone and the culture was grown over night at $37^{\circ} \mathrm{C}$. Glass bottles with $1.5 \mathrm{~L}$ TB supplemented with $100 \mu \mathrm{g} / \mathrm{mL}$ ampicillin and $500 \mu \mathrm{L}$ antifoam 204 (Sigma, München, Germany) were inoculated with the overnight culture. The O.D.600 was adjusted to 0.1 and incubated at $37^{\circ} \mathrm{C}$ until an O.D.600 of 1.5 to 5 was reached. The temperature of the water bath was then reduced to $25^{\circ} \mathrm{C}$. After $1 \mathrm{~h}, \mathrm{scFv}$ expression was induced by addition of $50 \mu \mathrm{M}$ IPTG. The cultivation was continued for $3 \mathrm{~h}$ resulting in a final O.D.600 of 2 to 7 depending on the antibody clone. E. coli cells were harvested by centrifugation at 4,400xg (Sorvall Zentrifuge RC6 Plus, Rotor F9S-4x1000Y) for $10 \mathrm{~min}$ at $4^{\circ} \mathrm{C}$. The pellet was resuspended in $60 \mathrm{~mL}$ ice-cold PE-buffer pH 8 (20\% (w/ v) sucrose, $50 \mathrm{mM}$ Tris, $1 \mathrm{mM}$ EDTA) and was incubated on ice for $20 \mathrm{~min}$ while shaking. Afterwards the sample was centrifuged at 20,000xg and $4^{\circ} \mathrm{C}$ for $30 \mathrm{~min}$ (Sorvall Zentrifuge RC6 Plus, Rotor F12-6x500y). The supernatant (periplasmatic preparation) was filled into a fresh glass bottle and kept on ice. The pellet was resuspended in $60 \mathrm{~mL}$ ice-cold OS-buffer ( $5 \mathrm{mM} \mathrm{MgSO}_{4}$ in $\mathrm{dH}_{2} \mathrm{O}$ ) and was incubated on ice while shaking. After $20 \mathrm{~min}$ the preparation was centrifuged at 20,000xg and $4^{\circ} \mathrm{C}$ for $30 \mathrm{~min}$ (Sorvall Zentrifuge RC6 Plus, Rotor F12$6 \mathrm{x} 500 \mathrm{y}$ ). The supernatant (osmotic shock fraction) was combined with the periplasmatic preparation and was used for protein purification.

\section{IMAC purification of ScFv}

Antibody fragments were purified by affinity chromatography using IMAC. Chromatography using Profinia (BioRad) and $1 \mathrm{~mL}$ FF-crude column (GE Healthcare, München, Germany) was performed according to the manufacturer's instruction. The protein solution was adjusted to $10 \mathrm{mM}$ imidazol containing buffer $(20 \mathrm{mM}$ $\mathrm{Na}_{2} \mathrm{HPO}_{4}, 500 \mathrm{mM} \mathrm{NaCl}, 10 \mathrm{mM}$ imidazol) for loading. The column was washed one time with $10 \mathrm{mM}$ imidazol buffer $\left(20 \mathrm{mM} \mathrm{Na}_{2} \mathrm{HPO}_{4}, 500 \mathrm{mM} \mathrm{NaCl}, 10 \mathrm{mM}\right.$ imidazol). Five hundred $\mathrm{mM}$ imidazol was used for elution, followed by desalting and storage in PBS.

\section{Titration ELISA using ScFv}

For the $\mathrm{scFv}$ titration ELISA the antigen was coated as described above (Enzyme linked immunosorbent assay (ELISA) for verification of immunogenic proteins). The ELISA was performed as described above (Identification of monoclonal scFv using ELISA) with one modification: a dilution series of IMAC purified $\mathrm{ScFv}$ was used instead of the scFv supernatant. The EC50 values (antibody concentration at the half maximal binding) are deduces from this titration ELISA.

\section{Detection of the immunogenic proteins by immunostain using SCFv}

Purified immunogenic proteins were separated by $12 \%$ SDS-PAGE. Western Blotting on PVDF (Polyvinylidenfluorid) membranes of gels was performed using the Mini Trans-Blot ${ }^{\circledR}$ system (BioRad). The membrane was blocked with $2 \%(\mathrm{w} / \mathrm{v})$ skimmed milk powder in PBST over night.

The antigens were detected with $20 \mu \mathrm{g} / \mathrm{mL} \mathrm{scFv}$ for $1 \mathrm{~h}$ at RT. The scFv myc-tag was detected with mouse anti myc-tag (9E10, Sigma, Taufkirchen, Germany) for $1 \mathrm{~h}$, followed by goat anti-mouse (Fc specific) (Sigma) conjugated with alkaline phosphatase $(1: 20,000)$ for $1 \mathrm{~h}$. The visualisation was performed by addition of BCIP (5bromo-4-chloro-3-indolyl phosphate) and NBT (nitroblue tetrazolium).

\section{Conclusion}

A "pipeline" from antigen identification to the generation of recombinant antibodies using phage diplay was shown. Here, novel immunogenic proteins of Salmonella Typhimurium were identified using phage display and validated using a panel of positive and negative sera. Afterwards, recombinant human antibody fragments were generated against these marker proteins.

\section{Competing interests}

The authors declare that they have no competing interests.

\section{Acknowledgements}

This project was supported by the BMBF (BioRegioN) and EFRE. Our special thanks go to Ronny Fischer from our EC office who helped with bureaucracy of EFRE/NBANK. We also thank to David Havlik, Jonas Zantow, Alex Pytka and David Becker for careful corrections on the manuscript.

\section{Author details}

${ }^{1}$ Technische Universität Braunschweig, Institut für Biochemie, Biotechnologie und Bioinformatik, Abteilung Biotechnologie, Spielmannstr.7, 38106

Braunschweig, Germany. ${ }^{2}$ IVD GmbH Heisterbergallee 12, 30453 Hannover Germany. ${ }^{3}$ Present address: vaxxinova GmbH diagnostics, Johann-Krane-Weg 42, 48149 Münster, Germany.

\section{Authors' contributions}

TM and SM performed most of the experiments and helped to draft the manuscript. TS and AF performed some of the experiments and participated in the design and coordination of the study. JSS, SD, GFG and KSM particpated in the design and coordination of the study and helped to write the paper. $\mathrm{MH}$ and JSS wrote the grant application. MH particpated in the design and coordination of the study wrote the publication. All authors read and approved the final manuscript.

Received: 23 January 2012 Accepted: 25 May 2012

Published: 15 June 2012

\section{References}

1. Fookes M, Schroeder GN, Langridge GC, Blondel CJ, Mammina C, Connor TR, Seth-Smith H, Vernikos GS, Robinson KS, Sanders M, Petty NK, Kingsley RA, Bäumler AJ, Nuccio S-P, Contreras I, Santiviago CA, Maskell D, Barrow P, Humphrey T, Nastasi A, Roberts M, Frankel G, Parkhill J, Dougan G, Thomson NR: Salmonella bongori provides insights into the evolution of the Salmonellae. PLoS Pathog 2011, 7:e1002191.

2. Guibourdenche $M$, Roggentin $P$, Mikoleit M, Fields PI, Bockemühl J, Grimont PAD, Weill F-X: Supplement 2003-2007 (No. 47) to the White-KauffmannLe Minor scheme. Res Microbiol 2010, 161:26-29. 
3. van der Wolf PJ, Peperkamp NH: Salmonella (sero)types and their resistance patterns in pig faecal and post-mortem samples. Vet $Q 2001$, 23:175-181.

4. Jacobsen A, Hendriksen RS, Aaresturp FM, Ussery DW, Friis C: The Salmonella enterica pangenome. Microb Ecol 2011, 62:487-504.

5. European Food Safety Authority, European Centre for Disease Prevention and Control: The European Union Summary Report on Trends and Sources of Zoonoses, Zoonotic Agents and Food-borne Outbreaks in 2009. EFSA Journal 2011, 9:1-378.

6. Little CL, Richardson JF, Owen RJ, de Pinna E, Threlfall EJ: Campylobacter and Salmonella in raw red meats in the United Kingdom: prevalence, characterization and antimicrobial resistance pattern, 2003-2005. Food Microbiol 2008, 25:538-543.

7. Menz G, Aldred P, Vriesekoop F: Growth and survival of foodborne pathogens in beer. J Food Prot 2011, 74:1670-1675.

8. Bugarel M, Granier SA, Weill F-X, Fach P, Brisabois A: A multiplex real-time $P C R$ assay targeting virulence and resistance genes in Salmonella enterica serotype Typhimurium. BMC Microbio/ 2011, 11:151.

9. Roesler U, Szabo I, Matthies C, Albrecht K, Leffler M, Scherer K, Nöckler K, Lehmann J, Methner U, Hensel A, Truyen U: Comparing validation of four ELISA-systems for detection of Salmonella derby- and Salmonella infantis-infected pigs. Berl Munch Tierarztl Wochenschr 2011, 124:265-271.

10. Farmer JJ III: Enterobacteriaceae: introduction and identification. In Manual of Clinical Microbiology:: ASM Press; 1999:442-458.

11. Gaillot O, di Camillo P, Berche P, Courcol R, Savage C: Comparison of CHROMagar Salmonella medium and hektoen enteric agar for isolation of salmonellae from stool samples. J Clin Microbiol 1999, 37:762-765.

12. Silverman AP, Kool ET: Quenched autoligation probes allow discrimination of live bacterial species by single nucleotide differences in rRNA. Nucleic Acids Res 2005, 33:4978-4986.

13. Alvarez J, Sota M, Vivanco AB, Perales I, Cisterna R, Rementeria A, Garaizar J: Development of a multiplex PCR technique for detection and epidemiological typing of salmonella in human clinical samples. J Clin Microbiol 2004, 42:1734-1738

14. Wang H, Li Y, Wang A, Slavik M: Rapid, sensitive, and simultaneous detection of three foodborne pathogens using magnetic nanobeadbased immunoseparation and quantum dotbased multiplex immunoassay. J Food Prot 2011, 74:2039-2047.

15. Nielsen B, Baggesen D, Bager F, Haugegaard J, Lind P: The serological response to Salmonella serovars typhimurium and infantis in experimentally infected pigs. The time course followed with an indirect anti-LPS ELISA and bacteriological examinations. Vet Microbiol 1995, 47:205-218.

16. Steinbach $G$, Staak C: Assessment of the Salmonella burden in slaughter pigs through the results of meat-juice-ELISA. Berl Munch Tierarzt/ Wochenschr 2001, 114:174-178.

17. van der Heijden HM: First international ring trial of ELISAs for Salmonellaantibody detection in swine. Berl Munch Tierarztl Wochenschr 2001, 114:389-392.

18. Kuhn KG, Falkenhorst G, Ceper TH, Dalby T, Ethelberg S, Mølbak K, Krogfelt KA: Detecting non-typhoid Salmonella in humans by ELISAs: a literature review. J Med Microbiol 2012, 61:1-7.

19. Delvecchio VG, Connolly JP, Alefantis TG, Walz A, Quan MA, Patra G, Ashton JM, Whittington JT, Chafin RD, Liang X, Grewal P, Khan AS, Mujer CV: Proteomic profiling and identification of immunodominant spore antigens of Bacillus anthracis, Bacillus cereus, and Bacillus thuringiensis. Appl Environ Microbiol 2006, 72:6355-63.

20. Huntley JF, Conley PG, Hagman KE, Norgard MV: Characterization of Francisella tularensis outer membrane proteins. J Bacteriol 2007, 189:561-74.

21. Jacobsen ID, Meens J, Baltes N, Gerlach G-F: Differential expression of noncytoplasmic Actinobacillus pleuropneumoniae proteins induced by addition of bronchoalveolar lavage fluid. Vet Microbiol 2005, 109:245-56.

22. LaFrentz BR, LaPatra SE, Call DR, Wiens GD, Cain KD: Identification of immunogenic proteins within distinct molecular mass fractions of Flavobacterium psychrophilum. J Fish Dis 2011, 34:823-830.

23. Meens J, Selke M, Gerlach G-F: Identification and immunological characterization of conserved Mycoplasma hyopneumoniae lipoproteins Mhp378 and Mhp651. Vet Microbiol 2006, 116:85-95.

24. Zhao Z, Yan F, Ji W, Luo D, Liu X, Xing L, Duan Y, Yang P, Shi X, Lu Z, Wang $X$ : Identification of immunoreactive proteins of Brucella melitensis by immunoproteomics. Sci China Life Sci 2011, 54:880-887.
25. Smith GP: Filamentous fusion phage: novel expression vectors that display cloned antigens on the virion surface. Science 1985, 228:1315-7.

26. Dübel S, Stoevesandt O, Taussig MJ, Hust M: Generating recombinant antibodies to the complete human proteome. Trends Biotechnol 2010, 28:333-339.

27. Hoogenboom HR: Selecting and screening recombinant antibody libraries. Nat Biotechnol 2005, 23:1105-16.

28. Thie H, Meyer T, Schirrmann T, Hust M, Dübel S: Phage display derived therapeutic antibodies. Curr Pharm Biotechnol 2008, 9:439-446.

29. Winter G, Griffiths AD, Hawkins RE, Hoogenboom HR: Making antibodies by phage display technology. Annu Rev Immunol 1994, 12:433-55.

30. Crameri R, Kodzius R, Konthur Z, Lehrach H, Blaser K, Walter G: Tapping allergen repertoires by advanced cloning technologies. Int Arch Allergy Immunol 2001, 124:43-7.

31. Govarts C, Somers K, Hupperts R, Stinissen P, Somers V: Exploring cDNA phage display for autoantibody profiling in the serum of multiple sclerosis patients: optimization of the selection procedure. Ann N Y Acad Sci 2007, 1109:372-84.

32. Naseem S, Meens J, Jores J, Heller M, Dübel S, Hust M, Gerlach G-F: Phage display-based identification and potential diagnostic application of novel antigens from Mycoplasma mycoides subsp. mycoides small colony type. Vet Microbiol 2010, 142:285-292.

33. Rhyner C, Weichel M, Flückiger S, Hemmann S, Kleber-Janke T, Crameri R: Cloning allergens via phage display. Methods 2004, 32:212-8.

34. Rosander A, Guss B, Frykberg L, Björkman C, Näslund K, Pringle M: Identification of immunogenic proteins in Treponema phagedenis-like strain V1 from digital dermatitis lesions by phage display. Vet Microbio/ 2011, 153:315-322.

35. Jacobsson K, Frykberg L: Shotgun phage display cloning. Comb Chem High Throughput Screen 2001, 4:135-143.

36. Jacobsson K, Rosander A, Bjerketorp J, Frykberg L: Shotgun Phage Display Selection for Bacterial Receptins or other Exported Proteins. Biol Proced Online 2003, 5:123-135

37. Hust M, Meysing M, Schirrmann T, Selke M, Meens J, Gerlach G-F, Dübel S: Enrichment of open reading frames presented on bacteriophage M13 using hyperphage. Biotechniques 2006, 41:335-42.

38. Kügler J, Nieswandt S, Gerlach GF, Meens J, Schirrmann T, Hust M: Identification of immunogenic polypeptides from a Mycoplasma hyopneumoniae genome library by phage display. Appl Microbiol Biotechnol 2008, 80:447-58.

39. Hust M, Meyer T, Voedisch B, Rülker T, Thie H, El-Ghezal A, Kirsch Ml, Schütte $M$, Helmsing S, Meier D, Schirrmann T, Dübel S: A human scFv antibody generation pipeline for proteome research. J Biotechnol 2011 152:159-170.

40. Rondot S, Koch J, Breitling F, Dübel S: A helper phage to improve single-chain antibody presentation in phage display. Nat Biotechnol 2001, 19:75-8.

41. Soltes G, Hust M, Ng KKY, Bansal A, Field J, Stewart DIH, Dübel S, Cha S, Wiersma EJ: On the influence of vector design on antibody phage display. J Biotechnol 2007, 127:626-37.

42. Mollova S, Retter I, Hust M, Dübel S, Müller W: Analysis of single chain antibody sequences using the VBASE2 Fab analysis tool. In Antibody Engineering. 2nd edition. Heidelberg/New York: Springer Verlag; 2010:3-10.

43. Hust M, Steinwand M, Al-Halabi L, Helmsing S, Schirrmann T, Dübel S: Improved microtitre plate production of single chain Fv fragments in Escherichia coli. N Biotechnol 2009, 25:424-428.

44. McCafferty J, Griffiths AD, Winter G, Chiswell DJ: Phage antibodies: filamentous phage displaying antibody variable domains. Nature 1990, 348:552-4.

45. Pershad K, Pavlovic JD, Gräslund S, Nilsson P, Colwill K, Karatt-Vellatt A, Schofield DJ, Dyson MR, Pawson T, Kay BK, McCafferty J: Generating a panel of highly specific antibodies to 20 human $\mathrm{SH} 2$ domains by phage display. Protein Eng Des Sel 2010, 23:279-288.

46. Colwill K, Persson H, Jarvik NE, Wyrzucki A, Wojcik J, Koide A, Kossiakoff AA, Koide S, Sidhu S, Dyson MR, Pershad K, Pavlovic JD, Karatt-Vellatt A, Schofield DJ, Kay BK, McCafferty J, Mersmann M, Meier D, Mersmann J, Helmsing S, Hust M, Dübel S, Berkowicz S, Freemantle A, Spiegel M, Sawyer A, Layton D, Nice E, Dai A, Rocks O, Williton K, Fellouse FA, Hersi K, Pawson T, Nilsson P, Sundberg M, Sjöberg R, Sivertsson A, Schwenk JM, Takanen JO, Hober S, Uhlén M, Dahlgren L-G, Flores A, Johansson I, Weigelt J, Crombet L, Loppnau P, Kozieradzki I, Cossar D, Arrowsmith CH, Edwards AM, Gräslund 
S: A roadmap to generate renewable protein binders to the human proteome. Nat Methods 2011, 8:551-558.

47. Breitling F, Dübel S, Seehaus T, Klewinghaus I, Little M: A surface expression vector for antibody screening. Gene 1991, 104:147-53.

48. Miltiadou DR, Mather A, Vilei EM, Du Plessis DH: Identification of genes coding for B cell antigens of Mycoplasma mycoides subsp. mycoides Small Colony (MmmSC) by using phage display. BMC Microbiol 2009, 9:215.

49. Kodzius R, Rhyner C, Konthur Z, Buczek D, Lehrach H, Walter G, Crameri $R$ : Rapid identification of allergen-encoding CDNA clones by phage display and high-density arrays. Comb Chem High Throughput Screen 2003, 6:147-54.

50. González E, Robles Y, Govezensky T, Bobes RJ, Gevorkian G, Manoutcharian $\mathrm{K}$ : Isolation of neurocysticercosis-related antigens from a genomic phage display library of Taenia solium. J Biomol Screen 2010, 15:1268-1273.

51. Cárcamo J, Ravera MW, Brissette R, Dedova O, Beasley JR, Alam-Moghé A, Wan C, Blume A, Mandecki W: Unexpected frameshifts from gene to expressed protein in a phage-displayed peptide library. Proc Natl Acad Sci USA 1998, 95:11146-11151.

52. Goldman E, Korus M, Mandecki W: Efficiencies of translation in three reading frames of unusual non-ORF sequences isolated from phage display. FASEB J 2000, 14:603-611.

53. Selke M, Meens J, Springer S, Frank R, Gerlach G-F: Immunization of pigs to prevent disease in humans: construction and protective efficacy of a Salmonella enterica serovar Typhimurium live negative-marker vaccine. Infect Immun 2007, 75:2476-2483.

54. Michels J, Geyer A, Mocanu V, Welte W, Burlingame AL, Przybylski M: Structure and functional characterization of the periplasmic N-terminal polypeptide domain of the sugarspecific ion channel protein ( $\mathrm{ScrY}$ porin). Protein Sci 2002, 11:1565-1574

55. Zhou D, Hardt WD, Galán JE: Salmonella typhimurium encodes a putative iron transport system within the centisome 63 pathogenicity island. Infect Immun 1999, 67:1974-1981.

56. Rong G, Zhong R, Lleo A, Leung PSC, Bowlus CL, Yang G-X, Yang C-Y, Coppel RL, Ansari AA, Cuebas DA, Worman HJ, Invernizzi P, Gores GJ, Norman G, He X-S, Gershwin ME: Epithelial cell specificity and apotope recognition by serum autoantibodies in primary biliary cirrhosis. Hepatology 2011, 54:196-203

57. Scholl D, Cooley M, Williams SR, Gebhart D, Martin D, Bates A, Mandrell R: An engineered R-type pyocin is a highly specific and sensitive bactericidal agent for the food-borne pathogen Escherichia coli 0157: H7. Antimicrob Agents Chemother 2009, 53:3074-3080.

58. Meyer T, Stratmann-Selke J, Meens J, Schirrmann T, Gerlach GF, Frank R, Dübel S, StrutzbergMinder K, Hust M: Isolation of scFv fragments specific to OmpD of Salmonella Typhimurium. Vet Microbiol 2011, 147:162-169.

59. Dalby T, Strid MA, Beyer NH, Blom J, Mølbak K, Krogfelt KA: Rapid decay of Salmonella flagella antibodies during human gastroenteritis: a follow up study. J Microbiol Methods 2005, 62:233-243.

60. Schofield DJ, Pope AR, Clementel V, Buckell J, Chapple SD, Clarke KF, Conquer JS, Crofts AM, Crowther SRE, Dyson MR, Flack G, Griffin GJ, Hooks Y, Howat WJ, Kolb-Kokocinski A, Kunze S, Martin CD, Maslen GL, Mitchell JN, O'Sullivan M, Perera RL, Roake W, Shadbolt SP, Vincent K, Warford A, Wilson WE, Xie J, Young JL, McCafferty J: Application of phage display to high throughput antibody generation and characterization. Genome Biol 2007, 8:R254.

61. Frenzel A, Fröde D, Meyer T, Schirrmann T, Hust M: Generating Recombinant Antibodies for Research, Diagnostics and Therapy Using Phage Display. Curr Biotech 2012, 1:33-41.

62. Pereira B, Benedict CR, Le A, Shapiro SS, Thiagarajan P: Cardiolipin binding a light chain from lupus-prone mice. Biochemistry 1998, 37:1430-1437.

63. Sambrook J, Russell D: Molecular cloning: a laboratory manual. 3rd edition. New York: Cold Spring Harbor Laboratory Press; 2001.

64. Schirrmann T, Hust M: Construction of human antibody gene libraries and selection of antibodies by phage display. Methods Mol Biol 2010, 651:177-209.

\section{doi:10.1186/1472-6750-12-29}

Cite this article as: Meyer et al:: Identification of immunogenic proteins and generation of antibodies against Salmonella Typhimurium using phage display. BMC Biotechnology 2012 12:29.

\section{Submit your next manuscript to BioMed Central and take full advantage of:}

- Convenient online submission

- Thorough peer review

- No space constraints or color figure charges

- Immediate publication on acceptance

- Inclusion in PubMed, CAS, Scopus and Google Scholar

- Research which is freely available for redistribution 